\title{
Producer with a Mission
}

\author{
By Gerald Pratley \\ Spring 1995 Issue of KINEMA
}

\section{ROCK DEMERS: PRODUCER WITH A MISSION}

Ten years ago a nondescript two-story office building on rue Roy in the lovely St. Denis and St. Laurent district of Montréal became the office and operating headquarters of a new company called Productions la Fête initiated by Rock Demers, a well respected and admired man about film in Québec. Dedicated to making sensible family films on a regular basis appealing to children and parents alike not many observers in or out of the business gave the project much chance of success. Demers' admirers praised him for his courage, his detractors were smugly certain he would fail. The best that could be expected would be a hopeful first, followed by a few more and a fade out, and then a "for rent" sign in the window.

But today, in the tenth anniversary year, the second floor is filled with constant activity; the original staff of three is now thirteen taking care of constant phone calls and the comings and goings of film people, both creative and financial. The production centre is continually busy, the entrance halls and walls are covered with pictures, posters and diplomas reflecting the considerable achievements and successes of this now firmly established company we used to know only as Faroun Films, a small, specialised distributor of European pictures.

The reassuring fact is that Productions la Fête is doing far more with a staff of thirteen than many other Canadian companies are doing with three times as many. It not only raises the money to make the films but distributes, publicizes, markets and sells them around the world. A constant presence on the festival circuit, the company follows up with ancillary deals involving tv, video and educational use.

All this activity is carried out by Rock Demers with a quiet persistence, dogged determination, and a gentlemanly grace and honesty almost unknown in movie circles today. He justifiably celebrates his decade of hard work with the satisfaction of knowing that his series, Tales for All has grown into a library of 15 timeless films and brought him into a fruitful working relationship with dozens of writers-directors, among them André Melançon, Michael Rubbo, Jean-Claude Lord and Jean Beaudry. He has travelled the world to places known and unknown, meeting filmmakers, making joint production and distribution arrangements, sitting on festival juries, attending conferences on numerous subjects, meeting with political leaders; without fuss or fanfare he has blazed a trail as no other Canadian producer has done before or since. Five years ago, feeling the burden of success, Demers took on the shrewd and knowledgeable Kevin Tierney, formerly with David Novak's public-relations company. Now vice-president in charge of production, Tierney, with his open and lively personality, has also carried the company colours around the world making new contacts and achieving impressive market sales.

But in 1984, when Demers mounted the stairs to his new office he faced the future alone, to enter the thin ranks of Canadian filmmakers in a country then lacking a firmly-based indigenous structure to support them. Since he began though, Québec itself has become a remarkably consistent and often self-sufficient market the success of which, with its feature films for cinemas and tv, is due in no small measure to Demers' activity, his belief in Québec, and his support for Canadian films as a whole.

As founder of Productions La Fête and initiator of the Tales for All project, Demers has worked in virtually every aspect of cinema, from production to distribution and programming. His production of Canadian family-oriented movies has earned him the respect of the film profession throughout Canada and around the world. Not since the pioneer days of Mary Field's invaluable work in establishing the Children's Film Foundation in England during the 1950's has any producer other than Rock Demers devoted himself to the intelligent application of devising an entire, continuing series of family films for children and their parents. In 1984, motivated by the same sentiments which made Mary Field's work so exemplary, he began his 12-film programme, La Fête (Tales for All) with The Dog Who Stopped the War. Since then, the twelve films have been completed and as a result of their international success, both critically and commercially, Demers is considering extending the series of fifteen. 
This is a remarkable achievement in many ways; and the odds against finding success with such an idealistic project designed primarily for cinema showings for young audiences in a cinematic age of violence, vulgarity and noise, were immense. Demers seemed to be flying in the face of both economic and artistic reasoning: while many parents bemoaned the lack of family films (they went out only to see Disney) and usually ignored individual family films which have turned up over the years (usually from Britain, Swallows and Amazons, Beatrix Potter, etc.), most children watched television more than they went to the movies -- Mary Field, at least, had the Odeon Saturday morning club showings to depend on.

He was also faced with the additional burden of making his films in French and English (family audiences including young children can hardly be expected to read sub-titles); some have been shot in French and dubbed into English and vice versa. In each case, the dubbing (which most true cinema-lovers cannot abide and will not accept) is carried out with such care and technical expertise that few audiences for these films would be aware of it. Dubbing could also be excused on the grounds that while all the young players give excellent performances, their voices are not such an integral part of their portrayals as would be the voices of accomplished actors in dramas and comedies. Yet, in spite of all these difficulties facing him, Demers, with the support of private investors, the federal government's funding agency, Telefilm, the provincial government's funding agency, SOGIC, and many other groups, has succeeded beyond his quiet yet determined expectations. His faith in his project and in his audiences has been justified by the international acclaim given these films and the fact that they have, in the long run, recovered their costs, with their subsequent television showings (most films come around to the small screen in the end for their final income) and their video sales and rentals.

\section{Man with a Mission}

Rock Demers, now considered an epoch in Canadian film-making, is quite obviously a man with a mission. "There are not enough individuals concerned with developing the imagination of young people in the right way," he says. "I want to help children leave childhood and go into adulthood with certain values. This is the age when they will build the values they will carry with them for the rest of their lives."

Balding, rumpled and white-bearded, Rock Demers looks more like a friendly professor, a character out of one of his own movies, than a producer. After growing up on a farm in south eastern Quebec (he was born in 1933) he trained to become a teacher at the University of Montréal. While studying for his teaching certificate in the 1950's, he became involved in the creation of numerous ciné-clubs for various academic institutions in Québec. Later, in collaboration with a few friends, he began the film magazine Images. His interest in cinema led him to enrol at the Ecole Normale Supérieure de Saint-Cloud in Paris, where in 1958 he received a diploma in audio-visual technology, before undertaking research into cinema, television and children's theatre. During the following two years he travelled in Europe and Asia, all the while pursuing his interests in the communications media. It was during these travels that Rock Demers made his first contact with Eastern European cinema, then in its burgeoning days in Czechoslovakia, Poland and Hungary. There he became familiar with new names, new stories and new ways of seeing the world through cinema. Among film-makers he met with were Vojtch Jasný, Krzysztof Zanussi and Betislav Pojar -- the very same names that would, some 30 years later, become involved with Tales for All. Upon his return to Canada in 1960, his passion for quality movies led him to join with colleagues who had just started the first Montréal International Film Festival, and from 1962-1967 he served as the festival's director-general. The festival, the third of its kind in North America, invited the works of the new directors who had impressed Demers during his European travels.

Rock Demers left the Montréal Festival in 1968 to work full time on his company Faroun Films, first founded as a hobby in 1965. This company specialized in the import-export of movies, particularly those for young people, distributing films in Canada and selling to some 50 countries around the world. And among the titles Faroun distributed in North America was an early Márta Mészáros film Riddance.

It was in his capacity as President and Executive Director of Faroun Films that he came to production through investing in and distributing two films for young audiences, The Christmas Martian, directed by Bernard Gosselin, a science-fiction picture that preceded Spielberg's E.T., and Two Silent Friends, the story of a dog who saves a drowning child, directed by Paul Fritz-Nemeth.

During its 13 years of existence, Faroun Films acquired the rights to more than 200 feature and short films 
from over 20 different countries. Having developed a relatively unique expertise as a programmer of quality pictures, Demers convinced Radio-Canada to include in its schedule a series of films directed to children. It proved to be successful and, in 1969, the CBC television network decided to start the "CBC Children's Film Festival," based on the many good films Demers had screened for them. It was equally well received by its young viewers. The French network, ORTF, was not far behind in seeing the potential of such a series, and each year it purchased up to six features for young people from Faroun Films.

From 1977 to 1979, Demers devoted most of his energy to the formation of the Institut Québécois du Cinéma, a government agency responsible for assisting in the development of a private industry for the production, distribution, exhibition, research and conservation of cinema.

In 1978, he was awarded the Governor General's medal in recognition of his valuable contributions to the entire area of film. The London Film Festival, Ontario's Stratford Film Festival and the Canadian Film Institute, all paid homage to the work done by Rock Demers.

The Stratford Film Festival in Ontario, Canada -- this festival took place between 1971 - 1976 and was eventually replaced by the Toronto International Film Festival -- paid tribute to him on the Tenth Anniversary of Faroun Films recognising his pioneer work in bringing foreign-language films to Canada. He has always retained fond memories of his visits to Stratford and recalls even today "its friendliness, its friendships, and its deep interest and respect for the cinema."

He was one of the co-founders of the Cinémathèque Québécoise and a member of the Consultation Committee on the establishment of a Canadian film policy established in 1973 by the then Secretary of State, Gérard Pelletier.

Rock Demers previously headed the Québec Association of Film Distributors and more recently, the Québec Film and Video Producers Association, where he continues to be an active member of the executive. He has served on numerous film festival juries and has taught cinema at the University of Québec at Montréal. In 1987 he was awarded the coveted Albert-Tessier-Prize by the Québec government for his lifelong contributions to cinema.

\section{Long-Cherished Ambition}

In 1980, Demers put all this behind him, withdrew from all his connections and activities, to carry out his long-cherished ambition to make films which truly seemed worthwhile to him; movies for children and families. And he did something no other Canadian producer has ever done -- he laid down plans to make twelve films, faithfully carried out to this day against all the odds and realized without compromising his initial vision of quality entertainment in the form of "a learning experience of life for young people."

The project was so well-organised that he had commissioned scripts for eight of them before the first even started shooting. Unlike Disney films, the style varies from film to film, but they all conform to Demers' basic principles: the leading roles must be played by children 10 to 12 years old, the stories must appeal to audiences of all ages, and the scripts should avoid stereotyping characters as good or evil, that children of different races can live together, that boys and girls are equally adept at activities once thought of as being "girl's job" or "boy's job."

"My intuition is that the traditional concept of good versus evil told to children for generations has harmed humanity," thinks Rock Demers, "because it tells us unconsciously that the world is divided into two camps, like Protestant or Catholic, or Communist or Capitalist. I'm 57 and I've never met anyone who is all good or all bad. For this reason, my films usually have an affirmative and reconciliatory tone designed to bring children and adults together."

"I'm told that I'm old-fashioned, my films are whimsical, the moral values out-dated. I just know that with the audience I have attracted the identification process is so strong that it can heal wounds. Children have too much violence on TV, or unhappy homes or school lives. They may be entertained by Star Wars, Superman, Roger Rabbit, but these will never bring them the peace and warmth that my films can bring to them."

Over the years, Demers' films have amassed an encouraging total of over 100 prizes from around the world since Tale \# 1, The Dog Who Stopped the War was released in late 1984. Directed by André Melançon, 
a part of the Tales for All creative team, this film literally came out of nowhere to not only win some 13 international prizes, but to become the highest grossing Canadian film of the year.

While the success of the first Tale might have been thought of as a "lucky break," the success of the second a "fluke," the third a "coincidence" and the fourth "good timing," it is clear that the appropriate response to the success of these films is to admire their originality, their spirit and, above all, their quality.

It was followed by The Peanut Butter Solution (1985), written and directed by Michael Rubbo, which has been released across Canada, the United States and the rest of the world, collecting its share of international prizes, among which are the Public's Choice Award at the Laon Film Festival and a Gold Medal at Italy's Giffoni Festival.

In 1986, Rock Demers re-teamed with director André Melançon on Bach and Broccoli, shot on location in Montréal and Québec City. A box office phenomenon in Québec, its uniformly excellent reviews in both English and French Canada assured it a long and prosperous future at home and abroad. It, too, received a Silver Medal at the 1987 Moscow Festival as well as two honours from the Festival's Youth Jury for its "warmheartedness" and "fantasy." One month earlier, it swept the top four prizes at the First Algiers International Children's and Youth Film Festival in June of 1987. Its brilliant career reached new heights when it was awarded the top prize at the First International Francophone Film Festival held in 1987 in Martinique, where the jury chose it from among many worthy contenders. More recently, it was named the 1988 winner of the Parents' Choice Gold Medal Award. The Boston-based authority on a wide range of quality children's entertainment selected Bach and Broccoli over some of the world's best films for young children.

\section{International Co-production}

The fourth film in the series, The Young Magician, was the first of what was to become a familiar and important tenet of the Tales for All, an international co-production. Shot in Poland during the fall and winter of 1985-86 and directed by Waldemar Dziki it was followed by The Great Land of Small (Czechoslovakia) directed by Vojtch Jasný; Márta Mészáros' Bye Bye Red Riding Hood (Hungary); Summer of the Colt (Argentina) directed by André Melançon; Demers' contribution to van Gogh's 100th Anniversary, Vincent and $M e$ (France) directed by Michael Rubbo, and in Romania, Reach for the Sky directed by Elisabeta Bostan. Between these six titles -- following the first three Tales -- were six Québec-filmed stories making 15 in all.

Canada has a seemingly endless list of co-production treaties with other nations, very few of which benefit Canada or its filmmakers. Demers' films are the exception. They are either native to the country they are set in or an adroit mix of Canada and the co-producing country (a good example is Vincent and Me). What is also interesting to note is the different look and idiom of his European films, in much the same way as the children's stories of different countries differ in their writing and style. No attempt is made by the producer to impose a unified "look" to them. One of the strengths of Demers' films is the charming and natural performances of the children, usually unknown, untrained youngsters who seem to take to film-making with the same joy and enthusiasm as ducks take to water.

Rock Demers comments: "I wouldn't feel at home making exploitation films. I feel much more comfortable with family films. Besides, it's easier to work with children 10 to 12 who are about to leave childhood, than with professional actors. A child can accept doing 13 to 15 takes easier than an adult. However, I have never used children from one film in a following film. I would have trouble employing them again for similar roles. Children of this age change so fast; it takes two years from the start of filming to release and then they're teenagers. I call my projects childhood films, not children's films. There are fewer directors gifted in working with children than with adults.

"I have a valuable backlog of good scripts. I could easily make two films in the series every year until the end of the century. I'm thinking of making films for older audiences, although I'm not sure how they would be different. It may be simply a case of the story being told from the point of view of an adult and not a child. Otherwise, they would still present the hopeful side of life as I see it.

After thinking about it for a number of years, Demers has finally produced his first dramatic feature-length film for adult audiences. "I will tell you how this happened although I had not thought of taking this step 
until later. I had reached my 15th Tale, but most of the scripts sent to me over the past few years I had set aside. Then came the script from Micheline Lanctôt. I thought it was so wonderful and so new and that it would be such an important step in filmmaking here in Québec that I wanted to be part of it; so I decided to embark on this impossible mission with Micheline. I'm sure not everyone will like it, some will say it's a masterpiece, others not, but it's a very different film, very different and it's exciting and stimulating."

The result is La vie d'un héros (A Hero's Life) written and directed by Micheline Lanctôt, the outspoken, imaginative and independent filmmaker who will not compromise her ideas on how her films will be made and what they will say. Believing in her, Demers never interfered and after it was finished he described it as an important work concerning "myth, memory and remembrance, unfolding on many levels in its exploration of human relationships." It opened last year's Montréal World Film Festival to mixed reviews.

"My films, I think, will become a library for the future. The subjects do not date, they would simply slip into period pieces. We don't make a lot of money in the short term, but in the long term we are building up quite a library to sell to video and TV. And every time a new film comes out there's more interest in the previous ones. My films show children that life is not easy to go through, that there are difficulties in relationships, in understanding other people, and in adjusting to conditions around us. But that, in the end, it's worthwhile. Although I employ fantasy, I want to portray reality as it is."

Keeping costs down is a problem. Starting with two-million dollar budgets, Demers now finds that he must spend around three million and more to maintain quality. As the producer, Demers spends much of his time on the set. He does not interfere with his directors, but he watches to make sure that his ideas and beliefs are never compromised. In an industry noted for its unprincipled producers, Demers lives up to his name by being a rock of honesty and dependability. André Melançon says of him: "Unlike so many producers, Rock does not act like a real-estate agent. He's a businessman, yes, but he has an artistic vision and a strong ethical code."

For Kevin Tierney the Tenth Anniversary of Productions la Fête is bringing with it a period of new direction "in which the company is going to expand its position and production activity helped by our new and promising co-production with Pathé of France." The energetic and witty Tierney, now vice-president in charge of production, recalls the progress he has seen since joining the company just over five years ago and taking over responsibility for marketing and public relations. As does Rock Demers, Tierney involves himself with something of everything to keep production moving from the first to final stages.

"I started in marketing and advertising although I was interested really in production. I became interested in development and in choosing projects. Then on No.13 The Flying Sneaker, I became co-producer." Tierney then produced with Demers the five-part tv documentary Pierre Elliot Trudeau: Memoirs and the latest Tale, The Return of Tommy Tricker. "But I'm still deeply involved in foreign sales. Most people don't realize what a firm infrastructure we need to do this successfully and, most importantly, the organisation of Retrospectives and participation in Film Festivals everywhere, big or small.

"In any given year we receive I would say from 25 to 50 requests from festivals. We had to hire a special assistant just to take care of packing and shipping prints and keeping track of where they all were. The logic behind dealing with festivals is this: it is part of our market strategy to participate in as many as possible on a quality basis and to win as many prizes as possible, because prizes then become a way of identifying films without names, stars or major distributors behind them. This certainly has been the case where tv and video sales are concerned."

This method is part of the Demers/Tierney way of conceiving their films for the world market, with an international face and universal appeal, while remaining true to their indigenous settings. This has worked everywhere although not as successfully as they would like in the United States. "The market south of the border," says Tierney, "is becoming more xenophobic and this is my last and favourite battle: it comes down of course to the fundamental question of shooting in English. During the last five years we've seen specialised distributing companies like Miramax, Sony and Goldwyn grow by bringing in to the US successful foreign language films. One hopes that moviegoers who see them would want their children to see movies set in other places such as our Tales; but there is stranglehold on the video market ln the US and even when the 'buzzword' becomes 'family films' they mean of course Hollywood's family films -- which are not quite the 
same thing!

"Dubbing is a problem, I admit, mostly ln English-speaking countries. I'm not crazy on dubbed pictures either, but you can't sub-title for children. So, no matter how carefully we dub our French or other languages into English, matching the tone of the children's voices and even directing their emotional expression, we run into difficulties."

At the very outset, Demers was determined to do a film ln English, one in French and then a co-production in the language of the country in which it is made. He has stuck to this and it has worked out this way although not always in this order. Says Tierney, "We do all our own dubbing in Montréal, and we take it very seriously at great expense. We 'direct' the voices to obtain sound comparable to the original so far as this is possible."

Demers, with Tierney, starts his second decade with four ambitious steps forward: the first is the new coproduction plan with Pathé; the second is to start distributing the films of other producers; the third is to play an important role in Showcase the new specialty tv cable service from Toronto; and the fourth is Demers' realization of yet another dream: the creation of Children's Centres in major cities of the world to provide young people with opportunities to learn about and to enjoy plays, films, video, concerts and the arts in general.

"What's important" thinks Kevin Tierney, "in terms of our ten-year history, is that to congratulate ourselves, on the one hand, on the successful completion of a project that seemed unbelievably ambitious at the very beginning, is one thing; on the other hand, what is important for us is that we recognized in doing this that the films were designed from the very beginning, in Rock's vision, in response to a vacuum in the market: no one was making live-action films with the family audience in mind, I mean the kind of film for the elementary school market from 7 to 12, and I think in making films to appeal to these children we have really succeeded in creating a 'niche' in the film world. The challenge in the next decade is not only to maintain it but to expand on it.

"One of the steps we are taking, for example, is in acquiring films from around the world similar in intent, content and outlook to ours that we are fortunate to see at festivals but which are seldom seen outside their own countries. So we have created this new part of us solely to acquire and distribute these films under our banner for as many territories as possible."

The continuing struggle for Productions la Fête is that of all production companies: endeavouring to hold down ever-rising costs. Demers has managed adroitly, without his films looking 'low-budget', to keep his head above water. Says Tierney: "The way we have structured our finances is that all private investors have made money and we have recouped ours. The shelf life of children's films is considerably longer than most movies for the adult market. I'll give you a brief illustration: on our 10th anniversary we have had an offer from Radio Canada to re-acquire our first film, The Dog Who Stopped the War, offering more money than they did the first time round when they helped to get us started with an initial investment. This gives you some idea that the catalogue itself will be a long and worthwhile investment for Telefilm and SOGIC -and for us." Asked if Demers did all the financial arrangements, Tierney, whose comic sense never fails him, replied with tongue in cheek: "Yes, he does the macro financing and I do the micro."

\section{Separation}

Last September Québec faced a provincial election and the battle was between the Liberals, the (then) ruling party under premier Daniel Johnson, and the opposition and separatist party, the PQ under Jacques Parizeau (now the Premier of Québec), who vows to take Québec out of Confederation to become a separate country. This would do more harm to Québec than to Canada, and industry and the arts (among other matters) would be greatly affected. No conversations in Québec today are free from political comment. Both Rock Demers and Kevin Tierney are outspoken and decisive on the issue.

Demers is quite certain about his opinions on the matter of separation: "I think it will work out right because it would be such a disaster for Canada and Québec if we separated. Economically speaking citizens of this country can live together, but I think that in the long-term, Québec would disappear. So if we really care about French-language and culture and a different mood and place within our country, Québec has to stay with Canada. I will be very surprised if at the end of this the people of Québec will vote for separation. I 
expected the election of the separatist government, but when the time of the referendum arrives I think that as in the past the people will decide to stay within Canada."

Tierney agrees: "We have similar feelings about this troubling situation, coming as we do from two totally different ends and perspectives. We were both born and raised in the same place but come from two different cultures. His is French, mine is Anglo-Irish. I'm not suggesting for a moment that never the twain shall meet; I think we do meet as one, as Canadians but I think it's a generation difference which gives us a different view of it. He's very much a political animal and has been remarkably successful at being as Québécois and Canadian as anybody in this province and also a well-known French-Canadian federalist.

"No, I don't worry. I don't think separation is going to happen. It's not going to get better right now but it's not going to get worse. We are locked into an almost unsolvable, boring situation. Few are really prepared to go all the way with the risks entailed. The real repercussions would be very disturbing. Investors would pull out their money immediately, of this I have no doubt."

"When speaking of the ambitious plans he is determined to carry through to strengthen Productions la Fête, Rock Demers firmly believes that producers in Canada (and no doubt elsewhere) will be marginalised and not very successful unless or they find a powerful partner in Europe or the USA. "Working from Québec, Europe is more natural for us so we tried to find out who in Europe we would want to be associated with and, of course, Pathé was high among those on our list and we started conversations with them. We finally reached the agreement we announced recently which is so important to us in that Pathé would release our films widely in cinemas, on tv and video, in France. It is crucial at this point in the development of our company that we have such a partner who won't be bankrupt within three, five or ten years."

Looking back Demers takes on a remembering expression and says thoughtfully: "My biggest surprise has been over the years -- at least here ln Québec -- to see the films succeed so well in the cinemas, an affirmation of what I believed in the beginning, but knowing the film business, might not have happened. It has been a tremendous encouragement for me to keep going. Also to have won the Golden Reel Award (for the highest box-office returns in the Canadian market) twice, and only narrowly missing out for a third time. Also the fact that we opened up co-production arrangements with Hungary, Poland, Czechoslovakia and Argentina and then to follow up and sell our films in 104 countries, which is also most encouraging. Yet even after 15 films it's still difficult to find production money. What continues to give me the incentive to look for it is that each time after the release of our latest film, whether at home or abroad, I go to the cinemas and sit with the children and their families and see their response to them. It's so wonderful to see how fascinated they are by the characters on the screen and to hear them and laugh and cry. That gives me the impetus to keep going. In the beginning I thought I would go past eight, or ten, films; but after the success of the first two I put the objectives to 12 , then 15 , and now I'm quite sure I'll reach $20 . "$

Demers had such faith in and a vision of the future that when he opened up his company he had courageously purchased three screenplays with his own money. "But for my first, The Dog Who Stopped the War, it was impossible to raise money, but finally the francophone Radio Canada (CBC in English Canada) agreed to invest $\$ 35,000$. However, when I did finally find enough to start production, Radio Canada called to say they were withdrawing their commitment because on reflection they thought they were giving me a rope to hang myself with. They wanted to save me from what they thought was certain disaster but I was able to convince them to stay with my project. Now ten years later they are buying the film again for more money than they paid the first time. We were also able to get production going because André Melançon deferred his salary. I borrowed as much as I could from the bank, and gave everything I had as a guarantee."

Demers has woven a tapestry throughout his work linking point, purpose and theme within all his activities. "I turned to political documentaries because, in a way, they are the outcome, if you like, of the conditions which children grow up under, and we can see how life might well affect them. My original project was for four films in this series: Havel of Czechoslovakia, Trudeau of Canada, Gorbachev of Russia and the Dalai Lama of Tibet -- four politicians coming from completely different backgrounds who knew each other and have influenced each other; four politicians still alive at the end of this century who changed for the better the values of their time.

Because my films for children are in a simple way introducing, presenting or offering a set of values different 
from those in American films there was a link between what the kids were reading and seeing and what these men had been, or were doing, for their countries in this century. That was my idea to go in this direction but it will not be the main target now. It was impossible to make the remaining two. Someone else has made a film on the Dalai Lama and the film on Gorbachev is not possible now. I have met him, I have a letter from him accepting the project, but this was when he was in power. I went to see him in Moscow to make final arrangements. We talked in his office but within a few months he was deposed. But he still wanted to make this film with me and, as he said, he would now be able to speak his mind more freely. But Yeltsin has forbidden him to make this film. I find this impossible to believe, this unacceptable restriction on his freedom.

Here is a man who changed the world by what he did in his own country, and now this brutal Yeltsin who has replaced him has forbidden him to make this film. Last year he was invited to go to Italy for an important event and he was refused permission to leave. I have lost contact with him and I worry about what will happen to him and his wife. The world of course has no time to think about him now. Trudeau played a large part in convincing Gorbachev to change his mind about the political system in his country; it was Havel who, after becoming president of Czechoslovakia, invited the Dalai Lama to visit his country; then Havel met Gorbachev in Moscow -- so you see they would all have been linked by a common and vital theme. They were you might say a "thinking" international conference of their own!

With the promise, or threat, of the hundreds of specialty channels on the way to our living rooms, Demers was determined to travel along the 'information highway,' albeit if only as the minor, occasional participant. Hence his investment in Showcase. "This is a further outlet for our films and I think it will be a good commercial proposition in a channel providing all-fiction quality films. Prime time will be $100 \%$ Canadian programming, while at other times we'll show films and tv dramas from around the world, Europe, Asia and Latin-America, in both sub-titled and dubbed versions. Our partners are Alliance Films holding 55\% with the CBC, ourselves, and individual filmmakers such as Denise Roberts, Denys Arcand, Atom Egoyan and others holding the reminding shares. I'm a vice-president and Kevin is on the programme and access committee and we shall fight to see that promises made are promises kept. It will be an English-language channel across Canada including Québec, where sub-titling will of course be in French."

All of this means a larger overhead. "Yes, but we are not going to overload ourselves with the cost of new premises and all that goes with this. We had to raise money from Les Caisses du Pots to put these extra activities into place. We will increase our staff to 20 within the next 12 months on the distribution and production side. We are producing on an average of six million dollars a year but in five years we will certainly be up to 25 million a year with our volume of production and distribution, together with another project I have in mind.

This is the Children's Entertainment Centre we call Space for All where every day throughout the year there will be music, theatre and cinema for children on a full time stage. It is a place where every day of the week all year round there will be high quality entertainment for children in one specific place which will not be a theatre, but special premises where there will be shops with books and videos, where films will be shown on hi-definition television, with simple stages for music concerts and putting on plays, everything written for or by children -- an all-purpose entertainment and the arts place for study and enjoyment. The first will open in Montréal and we are working out a business plan with individuals who are waiting to open centres in Milan, Madrid, Paris, Brussels and Tokyo -- the start of an international network. This for me is the great project for the last ten years of my active life."

Rock Demers' love of children and his life-long interest ln their education comes from his early years when he decided to become a teacher. "People ask me now where did my interest in the education of young people in the arts begin, in caring about what they see, what they are taught and what they perceive the world and grown-ups to be. Well, you remember I intended to become a teacher and at the end of my studies I went to France to learn how to use audio-visual means in order to help teaching methods. Afterwards I went travelling around the world and met people who were making films for children. This was a great discovery for me and since then I have always followed this direction." 


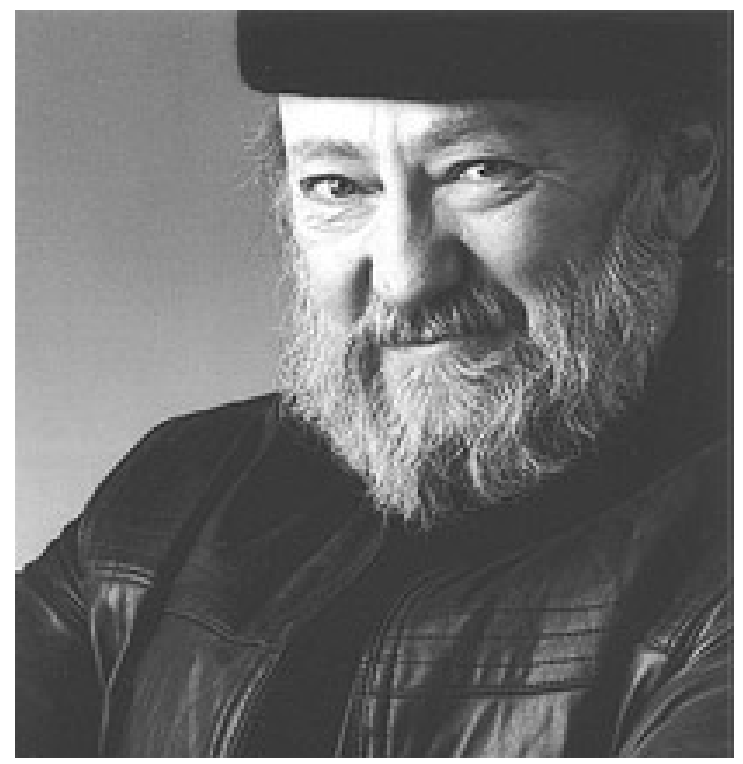

Figure 1: Rock Demers

\section{References}

\section{The Tales for All}

1. The Dog Who Stopped the War (La guerre des tuques), dir. André Melançon

2. The Peanut Butter Solution (Opération beurre de pinottes), dir. Michael Rubbo

3. Bach and Broccoli (Bach et Bottine), dir. André Melançon

4. The Young Magician (Le jeune magicien), dir. Waldemar Dziki (co-production with Poland)

5. The Great Land of Small (C'est pas parce qu'on est petit qu'on peut pas être grand!), dir. Vojtech Jasný

6. Tadpole and the Whale (La grenouille et la baleine), dir. Jean-Claude Lord

7. Tommy Tricker and the Stamp Traveller (Les aventuriers du timbre perdu), dir. Michael Rubbo

8. Summer of the Colt (Fierro ou l'été des Secrets), dir. André Melançon (co-production with Argentina)

9. Bye Bye Red Riding Hood (Bye Bye Chaperon Rouge), dir. Márta Mészáros (co-production with Hungary)

10. The Case of the Witch Who Wasn't (Pas de répit pour Mélanie), dir. Jean Beaudry

11. Vincent and Me (Vincent et moi), dir. Michael Rubbo (co-production with France)

12. Reach for the Sky dir. Elisabeta Bostan (co-prod. with Romania)

13. The Clean Machine (Tirelire Combines \& Cie), dir: Jean Beaudry

14. The Flying Sneaker dir: Bretislav Pojar

15. The Return of Tommy Tricker dir: Michael Rubbo

16. Letters from Santa

17. Dancing on the Moon

18. Hathi-The Elephant Boy

\section{Others}

Le Martien Noël (The Christmas Martian), dir: Bernard Gosselin (New version of the 1971 film)

\section{Documentary}

1992: Why Havel? (with Miloš Forman)

1993: Pierre Elliot Trudeau: Memoires (Memories) dir: Brian McKenna \& Pierre Castonguay

\section{Drama}

1994: La vie d'un Héros (A Hero's Life), dir. Micheline Lanctôt

\section{Rock Demers - Prizes Awarded}


1978 - THE GOVERNOR GENERAL'S MEDAL For his outstanding contributions to the Canadian Cinematographic Industry (Government of Canada)

1987 - ALBERT-TESSIER PRIZE For lifelong contribution to Québec cinema (Government of Québec, Canada)

1988 - AIR CANADA AWARD For his outstanding contribution to the Business of filmmaking in Canada (Academy of Canadian Cinema and Television)

1989 - FRANÇOIS TRUFFAUT PRIZE (XIXth Giffoni International Film Festival, Italy)

1990 - SPECIAL ACHIEVEMENT AWARD (2nd Estoril Coast International Film Festival, Portugal)

SPECIAL JURY PRIZE For his contribution to the improvement and promotion of the French language (Interdisciplinary Pedagogical Council of Québec, Canada)

BLUE RIBBON For his outstanding contribution to Canadian cinema (Festival of Canadian Television for Children, Banff, Canada)

CANADIAN VIDEO INDUSTRY AWARD OF ACHIEVEMENT (Premiere Magazine Toronto, Canada)

1990 CFTPA ACHIEVEMENT AWARD

(Canadian Film and Television Production Association)

OUTSTANDING CONTRIBUTION AWARD (5th Festival International du Film Francophone, Namur, Belgium)

1991 - LIFE ACHIEVEMENT AWARD (Canadian Film Celebration, Calgary, Alberta)

1992 - OFFICER OF THE ORDER OF CANADA For his outstanding contribution to the Canadian Film Industry (Government of Canada)

CHEVALIER DES ARTS ET DES LETTRES (Government of the French Republic)

1993 - TRIBUTE (XVIIth Montréal World Film Festival, Canada)

\section{Author Information}

Gerald PRATLEY, OC, LLD, started his career as film critic with the CBC. In 1969, he founded the Ontario Film Institute which he directed until 1990. He has written several books and numerous articles on film, including Torn Sprockets, a history of Canadian cinema. He taught Film History in universities in Toronto and Waterloo, Canada and holds three honorary degrees from Canadian and US universities.

Gerald A. Pratley (1923-2011) was born and educated in London, England, and came to Canada in 1946. He started working in Toronto for the $\mathrm{CBC}$ as a scriptwriter. He was drawn toward working in motion pictures, and became, in 1948, the CBC's first film critic and commentator.

Gerald Pratley broadcast three programmes a week, Pratley at the Movies, The Movie Scene, Music From the Films, and others, until 1975. During this time he also became the first post-war chairman of the Toronto Film Society, chairman of the Toronto and District Film Council and co-founder of the A-G-E Film Society and correspondent for international magazines such as Films and Filming, Film In Review, Variety, Hollywood Quarterly and International Film Guide. During the 1950s he wrote for Canadian Film Weekly and Canadian Film Digest.

He became known as a speaker on all aspects of motion picture art and industry, and was invited to teach film history at the University of Toronto, York University, University of Waterloo, Seneca College and Ryerson Polytechnical University, with individual lectures being given at many other Canadian and US universities and colleges. He has served as a member of various judging panels of competitions and festivals, being one of the members of the first Canadian Film Awards in 1949.

From 1970 to 1975 he was the director of the Stratford (Ontario) International Film Festival, and from 1969 to 1976 he was Chairman of the International Jury of the Canadian Film Awards. He has attended all the world's leading festivals of film, and in particular, for 30 years, the Cannes Festival as CBC correspondent. He has written six books, The Films of Frankenheimer: Forty Years in Film; The Cinema of John Frankenheimer; 
The Cinema of Otto Preminger; The Cinema of David Lean; The Cinema of John Huston, and Torn Sprockets, a history of the Canadian cinema.

Gerald Pratley has served on the Advisory Boards of the film departments of Ryerson Polytechnical University and Humber College, and as a member of the programme committee of TV Ontario. In 1968 he became the founder-director of the Ontario Film Institute of the Province of Ontario, an organization which has distinguished itself in archival holdings and public service and is known since 1990 as the Cinematheque of Ontario. He taught Film History courses at the Department of Film and Photography, Ryerson Polytechnic University, Toronto and the University of Waterloo.

In 1984, Gerald Pratley was made a Member of the Order of Canada and in 2003 Officer of the Order of Canada for his service to Canada through film appreciation. He holds Honorary Degrees in Letters and Fine Arts from York and Waterloo Universities (Ont., Canada) and Bowling Green State University (Ohio, USA).

In 2002, Gerald Pratley received a Special Genie Award from the Academy of Canadian Cinema \& Television in recognition of his lifelong dedication to the promotion and his exceptional support of Canadian cinema.

He died on 14 March 2011 in Ontario, Canada. 